\title{
Between Confrontation and Cooperation: Right to Water Advocacy in the Courts, on the Streets, and at the Capitols in the United States
}

\author{
Sabrina Kozikis ${ }^{1}$ and Inga T. Winkler ${ }^{1,2, *(D)}$ \\ 1 Institute for the Study of Human Rights, Columbia University, Interchurch Building, 475 Riverside Dr., \\ New York, NY 10015, USA; sk4359@columbia.edu \\ 2 Department of Legal Studies, Central European University, Quellenstr. 51, 1100 Vienna, Austria \\ * Correspondence: WinklerI@ceu.edu
}

check for

updates

Citation: Kozikis, S.; Winkler, I.T. Between Confrontation and Cooperation: Right to Water Advocacy in the Courts, on the Streets, and at the Capitols in the United States. Water 2021, 13, 3541. https://doi.org/10.3390/w13243541

Academic Editors: Bruce M. Wilson, Arkaja Singh, Daniel Brinks and Athanasios Loukas

Received: 27 September 2021 Accepted: 8 December 2021 Published: 10 December 2021

Publisher's Note: MDPI stays neutral with regard to jurisdictional claims in published maps and institutional affiliations.

Copyright: (c) 2021 by the authors. Licensee MDPI, Basel, Switzerland. This article is an open access article distributed under the terms and conditions of the Creative Commons Attribution (CC BY) license (https:// creativecommons.org/licenses/by/ $4.0 /)$.

\begin{abstract}
Communities across the United States face a widespread water crisis including risks of contamination, rate increases, shut-offs for non-payment, and dilapidating infrastructure. Against this background, a right to water movement has emerged which has found its strength in coalitionbuilding and collectivity. Activists demand change using the framing of "water is a human right", socially constructing the right to water from below. Based on more than 25 semi-structured interviews with water advocates and activists, our article explores how movement participants used the human rights framework to advocate for clean and affordable water for all. We used political opportunity theory and conceptions of government "openness" and "closedness" to examine when and how advocates decided to use confrontational and cooperative approaches. We identified a push and pull of different strategies in three key spaces: in the courts, on the streets, and at the Capitols. Advocates used adversarial approaches including protests and civil disobedience, reliance on human rights mechanisms, and to a more limited extent litigation simultaneously with cooperative approaches such as engaging with legislators and the development of concrete proposals and plans for ensuring water affordability. This adaptiveness, persistence, and ability to identify opportunities likely explains the movement's initial successes in addressing the water crisis.
\end{abstract}

Keywords: right to water; advocacy; activism; social movement; socio-economic rights; United States; political opportunity; coalition-building; collective action; human rights from below

\section{Introduction}

Communities across the United States face risks of water contamination, rate increases, shut-offs, and dilapidating infrastructure-resulting in a widespread water crisis. In 2015, 77 million residents relied on water that was in violation of the Safe Drinking Water Act [1]. Ten million U.S. homes face a threat of lead contamination in the pipes [2] (p. 14). Despite unsafe water and inadequate service, a recent analysis of 12 cities showed an average increase of $80 \%$ for combined water and sewerage rates from 2010 to 2018 [3]. When residents cannot afford to pay, many face disconnections [2] (p. 13), and in 2016 an average of $5 \%$ of U.S. homes in 73 water systems had their water disconnected due to non-payment [4] (p. 2). According to the US Water Alliance, over two million people in the U.S. do not have access to safe drinking water and sanitation [5] (p. 12).

Against this background of multiple, overlapping water quality and affordability crises in communities across the country, we see more and more civil society actors use the framing of "water is a human right" to demand change. Making this claim can seem a curious trend, considering the U.S.'s attitude towards domestic human rights and socioeconomic rights, in particular. The federal government largely does not acknowledge socioeconomic rights as rights but views them as aspirations or entitlements that are gained through hard work [6] (pp. 435-436). There is a perception that the U.S. Constitution and 
legislation guarantee the necessary rights rendering international human rights instruments unnecessary [6] (p. 435); see also [7]. The U.S. has not ratified the International Covenant on Economic, Social and Cultural Rights (ICESCR), and U.S. courts rarely rely on international human rights instruments.

At the international level, the U.S. government has supported the recognition of the human rights to water and sanitation. While the U.S. called for a vote and then abstained from voting on the original United Nations General Assembly resolution recognizing the right to water and sanitation in 2010 [8], the U.S. has since joined consensus, voted in favor, and even co-sponsored resolutions on the rights to water and sanitation, thus expressing its political support for these rights. However, in its explanations of position, the U.S. is always quick to point to the significance of the rights to water and sanitation for international cooperation and stresses that it has made water and sanitation a priority in official development assistance [9], thus relegating the rights to water and sanitation to challenges abroad. The U.S. also stresses that the rights to water and sanitation derive from the ICESCR, to which the U.S. is not a State party. Accordingly, the U.S. does not view the human rights to water and sanitation as domestically applicable and justiciable [10].

Historically, there was a time when socio-economic rights were not seen as unnecessary. Socio-economic rights were at the forefront of the New Deal era policies under President Franklin D. Roosevelt in the 1930s [11] (p. 289); [12] (p. 107). During the drafting of the Universal Declaration of Human Rights (UDHR) after World War II the U.S. was a strong proponent of the inclusion of socio-economic rights [13] (p. 896); [11] (p. 294). However, a shift in the acceptance of domestic socio-economic rights occurred between 1947 and 1948. The UDHR was adopted against the backdrop of the Cold War, during which the U.S. experienced a rising fear of communism, ideas of isolationism, and opposition to addressing racial inequalities as a backlash to New Deal era policies [13] (p. 895); [12] (p. 118).

For a long time, NGOs, too, have been hesitant to advance socio-economic rights through advocacy [14] (pp. 1-3); [15]. In the last two decades, however, we see a shift in the movement towards embracing socio-economic rights in their work [16-18] (p. 381), perhaps most notably in the context of health. "Healthcare is a human right" has become a calling card for domestic human rights on a public scale. To some extent, this language has entered the political landscape, for example being pushed to the forefront of the 2020 debates for the Democratic primaries, with candidates declaring healthcare as a human right on national television [19] and President Biden arguing on social media that "housing should be a right" [20].

A similar trend can be observed for the right to water. At the political level, Senator Bernie Sanders and Representative Brenda Lawrence co-authored an op-ed for The Guardian seeking to bring access to water to the forefront of political discourse. They explicitly stated that water is a human right [21]. Water activists look towards the human rights framework for their advocacy, forming behind a rallying cry that "water is a human right". As we explored in a companion paper, it seems perplexing that activists relied on the human right to water in a country that still challenges the need for socio-economic rights. Yet, activists expressed that the human rights framework provides empowerment and validation to the communities that are most impacted [22].

This article explores how advocates used the human right to water framework to work towards clean and affordable water for all. We find that advocates employed various strategies largely in social and political circles. Specifically, the article examines how activists and advocates participated in both confrontational and cooperative advocacy approaches in the courts, on the streets, and at the Capitols on local, state and national levels.

\section{Methods}

This article is based on semi-structured interviews with water advocates and activists in the U.S. relying on human rights. We interviewed twenty individuals in June and July 2018, complemented by an additional six persons in December 2020, who we identified through personal contacts in the National Coalition on the Human Rights to Water and 
Sanitation, online research, and snowballing. Interviewees included both professionalized advocates and local resident activists living in communities which face violations of the human right to water. A few participants engaged in right to water advocacy and coordination at the national level. Most participants were local advocates located in the Central Valley in California, Flint and Detroit in Michigan, and in Appalachia, specifically eastern Kentucky and southwestern West Virginia. While these regions are not exhaustive of the many civil society groups across the country mobilizing around the human right to water, they demonstrate the breadth and richness of community organizing (see [22] for more details). The interviews in 2018 were conducted face-to-face in the respective communities, while the interviews in 2020 were conducted online. They focused on engagement in human right to water advocacy, how activists utilized the framework of human rights, the reasoning for using the framework, and why and how they chose specific strategies of engagement. All but one interview were recorded and transcribed, they were then thematically coded for common themes in line with the framework set out by Virginia Braun and Victoria Clarke [23]. Interviews were complemented with media sources and legislation. The study was conducted in accordance with the Declaration of Helsinki, and the project was reviewed by Columbia University's Institutional Review Board under Protocol Number IRB-AAAR7902. All participants gave their written informed consent for inclusion before they participated in the study. We discussed attribution options with participants, and most participants opted to be identified by name, given that they are highly visible actors in the movement who have been very outspoken on many occasions. Most interviewees are thus named in the study, while the others have been anonymized.

\section{The Social Construction of the Right to Water from Below}

Against the backdrop of the U.S. relationship with socio-economic rights at the domestic level, it seems peculiar that activists turned towards the human rights framework, but this has become increasingly common. Across the country, the right to water emerged through large- and small-scale coalition building on various levels, from local communities to the international sphere, resulting in the social construction of the right to water from below. Such coalition building has trended within communities pushed to the margins, given their disproportionate struggles with water quality, affordability, and accessibility (see [22]). Coalitions have formed in grassroots organizations and civil society gatherings, as well as within larger, established non-governmental organizations that traditionally avoided embracing human rights frameworks. The exchanges and opportunities for mutual learning between these different levels have been essential to advance the movement.

Some notable organizations engaging with the human right to water include the Alabama Center for Rural Enterprise, the Environmental Justice Coalition for Water, the Community Water Center, the \#NoDAPL movement, Georgia WAND, Martin County Concerned Citizens, the Baltimore Right to Water Coalition, Food and Water Watch, the Unitarian Universalist Service Committee, the Color of Water, We the People of Detroit, the Michigan Welfare Rights Organization (MRWO), the New Mexico Environmental Law Center, Dig Deep, the Red Water Pond Road Community Association, the Campaign for Lead Free Water, among many others. Human rights language was found on organizations websites, within mission statements, and in direct community action. One such example was The Alliance for Appalachia. The coalition's website stated that they "value clean water and healthy ecosystems as fundamental human rights" [24] which integrated the human right to water into their mission statement.

Grassroots organizing in Martin County, Kentucky, illustrates these trends. For Nina McCoy, forming a concerned citizens group to unify the county following a coal slurry spill that polluted the water supply was the first step in coalescing the community around the human right to water [25]. For residents who may have been fearful of speaking up about water contamination due to the coal companies' involvement, the concerned citizens group allowed for collective action to grow the movement for clean water socially as well as politically. This coalition building provided the basis for subsequent advocacy 
through meetings with legislators and congressional briefings. In a similar vein, in the Central Valley in California, communities have been working with the Community Water Center to shift the perception of water as a human right. The collective acknowledgement that a community deserves clean water was a form of empowerment for communities unable to access clean and affordable water [26]. Similarly, MWRO has been advocating for low-income individuals in Michigan as an integral part of the fight to stop water shutoffs in Detroit. MWRO has worked directly with community members, centering their needs, and enabling residents to take control of the fight for water affordability. Sylvia Orduño explained that "the human rights work has allowed [them] to expand more of the conversations with people" [27].

The call to address racism has underpinned the human right to water movement in African-American communities in Michigan (Detroit and Flint) as well as amongst primarily rural, Latinx communities in California. Activists responded to governmental inaction and victim-blaming narratives claiming that water shut-offs occur because "poor Black folks" do not pay their bills [28]. More recently, the U.S. has seen large-scale support for the Black Lives Matter movement. For Patricia Jones, these external factors could help the human right to water movement continue forward [29]. Large-scale national "big white green groups" have begun to understand environmental racism and racial disparities in access to water and sanitation [29]. While localized movements have long been addressing racism in the face of water shut-offs, contamination, and inequity, national organizations have begun to understand the structural causes of the water crisis potentially opening opportunities for broader coalition-building.

In response, more and more organizations have centralized the human right to water to mobilize a coalition of individuals, grassroots organizations, and larger NGOs, allowing for a collective voice. Such coalition building has expanded into international movement building. MWRO organized an International Social Movements Gathering on Water and Affordable Housing in Detroit. The Gathering allowed for advocates not only from Michigan and the U.S. but from countries such as Italy, Mexico, and Venezuela to come together to develop strategies to demand affordability in water and housing [30]. One attendee, Paula Swearengin of the Ohio Valley Environmental Coalition, spoke directly to the need of national coalescing, "Appalachia stands with you. We protest, we rally, we fight our leadership that doesn't stand with us. We need national collaboration" [30]. The Gathering identified a collective need for advocates from across the country and abroad to learn from one another. Coalition building provides an opportunity for unified voices and collective power when demanding human rights.

More so than a legal framework, activists perceived and utilized human rights as a powerful framework that provides (symbolic) legitimacy for their advocacy [22]. While much of the earlier literature on socio-economic rights has focused on judicial enforcement (often motivated in response to challenges to the justiciability of socio-economic rights) [31,32], rights-based strategies are, in fact, much broader and more diverse. Here, our focus is on exploring how activists used the right to water that they have socially constructed from below in an environment that initially provided limited institutional, legislative, and judicial support. Instead, the coalescing on a community, state, national, and even international level between residents and organizations and the unification of people from diverse backgrounds has tapped into the social and political spheres, creating a movement from the ground up, which has provided the foundation for right to water advocacy taking root.

\section{Situating Strategic Choices for Right to Water Advocacy within Political Opportunities}

The strength of the right to water movement lies in its coalition-building and collectivity that has enabled activists to construct the right to water from below, which has imbued movement participants with power. Similar to Shareen Hertel's identification of a hybrid approach to rights-based social movements in India [33], we see a multi-pronged approach in the human right to water movement in the United States. Building on pre- 
vious work on the internal validation and collective identity developed through human rights [22] (see also [34]), we explore how activists and advocates used their power to act. They engaged on a community and social level ("on the streets"), within the political system ("at the Capitols"), and to a more limited extent in the judicial system ("in the courts"). The interviews with advocates and resident activists show that there was not one single avenue for engagement, but rather a network of engagement strategies, tactics, and mechanisms ranging from confrontational to cooperative in social spheres and political systems. Such strategies were often informed by the political climate of local, state, and sometimes national governments. Activists and organizers have consistently taken signals from the extent of governmental openness to determine engagement strategies. Alice Jennings explained this as a triple-pronged approach of "agitation, litigation, legislation and policy" [35].

We use political opportunity theory to analyze the movement's actions, successes, and failures in relation to the opportunities available [36]. Sidney Tarrow explains political opportunities as "consistent-but not necessarily formal or permanent-dimensions of the political environment that provide incentives for people to undertake collective action by affecting their expectations for success or failure" [37] (p. 85). Political opportunity theory attempts to explain how different social movements take place in relation to external factors, offering contextualization of a movement in relation to the world around them (see [38-41]). Political opportunity theory can help contextualize how the human right to water movement in the U.S. has taken shape through movement actions. Peter K. Eisinger (1973) examines governmental "openness" (i.e., more government responsiveness to constituents) and "closedness" (i.e., less government responsiveness to constituents). As others have described in other contexts, pragmatic advocates often put the lived experience of people struggling with human rights violations at the center without adopting one single approach, thus allowing them to respond to tactical openings. They "move beyond the adversarial remedial paradigm that dominates domestic justice .... . They do not consider adversarial procedures and court orders to be the best methods for challenging ESR violations and enforcing ESR mandates. But neither do they avoid such advocacy tools when appeal to the courts will build their campaigns' strategic power. When they do go to court, their reasons may have less to do with the potential effect of the judgment than the expressive force of the lawsuit or the potential to create a public spectacle or spark public movement at a press conference" [42] (p. 149).

We examine how advocates used the human right to water by situating the confrontational tactics ("the courts" and "the streets") and cooperative tactics ("the Capitols") in the context of political and non-political factors to show how the opportunities available to the movement influenced their decisions to move forward with one tactic over another. Local and state governments in the U.S. are not solely open or closed, rather they experience shift over times. The human right to water movement has carefully navigated these shifts to develop confrontational and cooperative strategies to achieve success. This push and pull of confrontational and cooperative approaches can be seen in the courts, on the streets, and at the Capitols, which we will explore in turn.

\subsection{The Courts}

Water advocates and activists have engaged in right-based litigation in domestic courts to a limited extent. Moreover, while these are not judicial mechanisms per se, they have also sought to engage with international and regional human rights mechanisms.

\subsubsection{Domestic Rights-Based Litigation}

While rights-based litigation is often perceived as the most immediate form of enforcing and advocating for human rights, in the U.S. the judicial sphere has played a limited role in right to water advocacy. Judicial engagement with international human rights law, and socio-economic rights in particular, is rare in the U.S. court system [43] (p. 312); [44] (p. 533). Britton Schwartz, a lawyer and human right to water advocate in California, explained 
that litigation is not always the right path: "I don't actually think [suing people is] even a good idea, even though [they've] found a hook to do it. Because these people have to deal with each other, and it's nice that we threaten litigation sometimes, right? Sometimes that's a really powerful stick, but a lot of times it's more about filling the gaps that are keeping people apart than pitting them against each other." [45].

Mark Fancher, a lawyer with the American Civil Liberties Union (ACLU) Michigan, explained that while the 1960s and 1970s saw "activist judges", in more recent years this has subsided and there is little room for innovation and creativity to incorporate international human rights law into the courtroom [28]. Another ACLU lawyer, Bonsitu Kitaba-Gabiglio, echoed this sentiment, noting that the underpinning belief in the U.S. that socio-economic rights are earned through hard work rather than guaranteed by the government is reflected in the thinking of judges, creating a challenge to human right to water litigation [46]. Patricia Jones, a longstanding human rights researcher and advocate within the U.S. human rights movement, argued that there are avenues within U.S. courts for human rights law through the ratification of treaties such as the Convention on the Elimination of All Forms of Racial Discrimination. However, this is challenged by the lack of education for U.S. judges in human rights and international law [29]. Given the lack of support on the part of judges, advocates primarily maintained their engagement on the streets and at the Capitols rather than in the judicial sphere.

There were exceptions, though: In at least one U.S. court case, litigants explicitly included the human right to water in their complaint. In the 2014 case, Lyda et al. v. City of Detroit, the plaintiffs filed a civil case against the city of Detroit in relation to the water shut-offs, citing not only civil violations but also a violation of the human right to water. They requested an injunction to stop the water shut-offs and to implement an incomebased affordability plan [47]. The Lyda case was in direct response to the vast number of 3000-5000 water shut-offs per week and actions by the government to mark the households who were behind on their payments with blue paint [35]. The government's lack of response to the movement's demands caused activists to move forward with litigation despite the challenges noted above [35]. This demonstrates a move toward confrontational strategies when governments are perceived as closed [36,38]. The Lyda case was supported by an amicus curiae brief based on human rights standards through the International Network on Economic, Social and Cultural Rights [48], but the court found explicitly that plaintiffs cannot rely on a right to water [47]. Such a ruling signaled to advocates that the courts were not a viable choice for ensuring water affordability. In response, advocates turned their efforts to other strategic advocacy, often through cooperative strategies and engagement with the city government to propose water affordability plans, as we discuss below.

However, years of advocacy for ensuring water affordability and ending water disconnections due to an inability to pay have not yet brought permanent results in Detroit. In response, advocates have recently returned to litigation. On 9 July 2019 the ACLU of Michigan filed a class action lawsuit (Taylor et al. $v$. City of Detroit) on behalf of a coalition of organizations against the City of Detroit to codify a water affordability plan and demand an end to the water shut-offs in the city. The complaint highlighted racial discrimination and the water shut-offs' impacts on the health of residents. The first line read "Water is a human right and basic necessity, especially in a time of pandemic" [49]. While the human rights framework was not centric to the legal approach in this case, it has entered the language of the lawsuit. The decision to incorporate human rights language in the Taylor case stemmed from the need to humanize the water crisis as well as to compare how the U.S. treats water compared to the rest of the world [46]. Human rights have continued to influence the framing of the water crisis in Detroit.

The Taylor case was built upon ideas surrounding water insecurity in the face of a pandemic, hoping that COVID-19 can be an external factor that pushes the needle forward on realizing the human right to water in Michigan $[35,46]$. In the light of the pending Taylor case and the impacts of COVID-19, the mayor of Detroit instilled a two-year moratorium on water shut-offs with the promise of working towards a comprehensive water affordability 
plan [35]. This step signals the success of combining confrontational efforts such as litigation and more cooperative strategies discussed below. It also shows how external forces beyond the movements' control, such as COVID-19, can shift an unresponsive government into a responsive one [35,46] (cf. also [38]). The movement demonstrated their strategical savviness by capitalizing on this shift to advance their goals.

\subsubsection{Engagement with International and Regional Human Rights Mechanisms}

Apart from domestic litigation, advocates have also engaged with international and regional human rights mechanisms through several United Nations (UN) Special Procedures, the Universal Periodic Review (UPR), and the Inter-American Commission on Human Rights (IACHR). Such engagement has provided a sense of validation [22]. The provision of space in which communities can be heard has reinforced the activists' lived experiences when the local, state, and federal governments continued to ignore their demands and failed to act.

Confrontational tactics can be seen through the engagement with UN Human Rights mechanisms as a way to disrupt the international image of the U.S. Turning outward can "name and shame" the country in the international arena. Advocates have engaged with several UN mandates: The Special Rapporteur on Water and Sanitation undertook a country mission in 2011 [50] and visited Detroit again at the invitation of civil society in 2014 together with the Special Rapporteur on Housing [51]; several mandates expressed their concern about the situation in Flint through communications addressed to the government [52]; in 2016, the Working Group on People of African Descent expressed its concern about the impact of lead contamination in Flint on African-Americans highlighting the racial disparities of the water crisis [53]; and the Special Rapporteur on Extreme Poverty visited Alabama and Appalachia in 2017 making the water and sanitation crisis part of his agenda. A team of journalists from The Guardian joined him and covered the visit in depth [54], greatly enhancing its visibility. In a highly-publicized exchange in the Human Rights Council, the Special Rapporteur drew renewed attention to the sanitation crisis. After U.S. Ambassador Nikki Haley withdrew the U.S. from the Human Rights Council and characterized the body as a cesspool [10], the Special Rapporteur opened his statement: "Speaking of cesspools, my report draws attention to those that I witnessed in Alabama as raw sewage poured into the gardens of people who could never afford to pay $\$ 30,000$ for their own septic systems in an area remarkably close to the State capital. I concluded that cesspools need to be cleaned up and governments need to act. Walking away from them in despair, as in Alabama, only compounds the problems" [55].

With regard to the visit to Detroit, Mark Fancher remembered, "the one time that I thought that the administration really got nervous ... on the border line of being distraught was when the United Nations came in at the invitation of a coalition of grassroots activists and organizations, when they came, and, you know, they observed and reported what they saw that made them very, very nervous, because they didn't want the world to know, what was happening here" [28].

These sentiments were echoed by advocates from California who saw the visit by the Special Rapporteur on Water and Sanitation as an opportunity to publicize the crisis and to grow awareness surrounding the movement [56]. The visit exposed the lived experiences of residents to the general public in California and beyond. There was a heightened concern amongst California residents after the $\mathrm{UN}$ visit about the water crisis, and residents themselves began reaching out to their elected officials asking how they were going to respond to the crisis [56].

The realization of the right to water was also addressed in the UPR, a UN human rights mechanism that is based on peer review and constructive engagement among States and hence less confrontational than other mechanisms [57]. Two recommendations from the second UPR cycle in 2015 took up the right to water [58], which the U.S. partially accepted [59]. Following this process, the U.S. government organized interagency Working Groups that addressed the water recommendations alongside others and provided oppor- 
tunities for civil society engagement [60]. While these were discontinued under the Trump administration, the Biden administration has begun to re-engage with the UPR process and has accepted recommendations from the third UPR cycle concluded in 2021, including on improving sanitation for marginalized communities [59].

Utilizing UN human rights mechanisms has reshaped the discourse into one of human rights violations, supported communities in building legitimate claims, and conveyed a sense of validation to activists [22]. International and regional mechanisms also served for "naming and shaming" to elevate visibility in an effort to apply pressure to the government [61]. However, utilizing human rights mechanisms has its limitations as they do not have direct enforcement powers to hold the U.S. accountable for human rights violations. For example, in 2015, the IACHR held a hearing on the human right to water in the Americas in which civil society organizations from the U.S. and several Latin American countries provided information to the Commission to shed light on the violations of the human right to water across the continent [62] (p. 492). The hearing provided a carefully orchestrated demonstration of the human rights violations people live with. Before the hearing, activists met and rehearsed, adjusting the timing and order of testimonies for the most powerful impact. The Commission acknowledged water affordability crises in cities such as Detroit, Baltimore, and Boston, and contamination within Indigenous communities including the Red Water Pond Road Community in New Mexico [62] (pp. 490, 492). Activists followed up by requesting another hearing focused on the U.S. which would present an opportunity to engage directly with U.S. government representatives. Yet, while acknowledging the importance of water and sanitation, the U.S. representative noted that the U.S. is not bound by the ICESCR and therefore this right is not justiciable in the U.S. [63] (23:15-30:00) without engaging substantively on the issues raised by advocates. Possibly with the exception of the initial phases of the UPR follow-up in 2015/16, responses by the federal government have largely remained disengaged and non-committal.

As advocates have engaged in formal, confrontational strategies in courts and the mechanisms available on the international level, limitations of these approaches have become apparent. The human right to water is not considered justiciable in the U.S. and therefore human rights-based strategies do not have the biggest impact in the courts. With regard to international advocacy, some UN engagement made U.S. government officials "very, very nervous" [28] as explained above. Yet, as can be seen in the 2016 hearing, the U.S. government often lacked genuine engagement, highlighting that this rather confrontational act did not sway the government into action, at least not directly. The purpose, though, of engaging in litigation and hearings was to bring attention to the crisis and to garner (international) recognition. Courts and international mechanisms were not the sole strategy used by advocates but formed part of a larger advocacy strategy that incorporated the confrontational and the cooperative. In other contexts, such advocacy has provided background legitimacy and a destabilization (or loosening) of institutional scripts that "can create an environment that supports institutions to change in the direction of greater ESR compatibility" [64] (p. 176). As such, even if it does not prompt immediate reactions, it lays the groundwork for further engagement.

\subsection{The Streets: Resistance and Civil Disobedience}

Advocates further achieved destabilization through marches, protests, rallies, and direct acts of civil disobedience as a means of making activists' voices heard to unresponsive governments [35]. When a government shows a high level of closedness, social movements often react with protest and civil disobedience to elicit a governmental response [38].

One of the most publicized resistance efforts took place in Michigan. Both Flint and Detroit have seen sustained efforts of activists taking to the streets to demand the human right to water as Detroit residents faced water shut-offs and Flint residents were poisoned by the water supply (see [65] for a detailed account of the struggle in Flint). In Detroit, the New York Times picked up a story of demonstrators marching in the streets chanting "fight, fight, water is a human right" [66]. Over the years, advocates have continued to demand 
the suspension of shut-offs, debt forgiveness for those who cannot afford their bills, and a more comprehensive water affordability program [67].

Paired with marches was civil disobedience [68]. Activists in Detroit blockaded trucks on their way to shut off residents' water $[69,70]$ (p. 12). One group of water rights activists known as the "Homrich 9" was charged with disorderly conduct, a criminal misdemeanor, in the summer of 2014 [71]. Homrich was a contractor used by the city of Detroit to shut off water services [72]. The protesters' goals were to keep the water on for Detroit residents as well as to bring light to the destructive policy and advocate for a system in which utility bills are based on a resident's ability to pay [67]. This act of civil disobedience not only brought the activists into the spotlight on the day of the blockade, but their trial drew significant attention afterwards, and their story was told and re-told, including at the Social Movements Gathering. Such "moments of power reversal get remembered and retold in ways that sustain their politicizing effect over time" [64] (p. 154).

Governmental inaction drove the human right to water movement to engage in confrontational tactics. Flint and Detroit advocates recognized the unresponsiveness of their government in the face of their demands. Alice Jennings explained this relationship and reaction to the government: "when something like the shut-offs happen ... or the complete and total just turning your back, you're not listening to us. You're not listening to us. So, we have to show you" [35]. Michigan's history of strong labor movements has not only educated people of how race, gender, and socio-economic inequalities intersect, but it has provided the human right to water movement with a framework on how to protest in the face of unresponsive governmental actors.

Michigan was not alone in relying on civil disobedience. Junior Walk of the Coal River Mountain Watch in West Virginia, an organization fighting against mountain top removal and the protection of the land and water from coal mining pollution recalled: "I've done a little bit of like direct action where getting arrested on surface mines, helping out with tree sits or blockades" [73]. As coal companies have continued to extract resources and pollute water without consequences, accountability, or regulation by the local governments, activists were reactionary. Where governments appeared closed, activists reacted with confrontational strategies that seek to generate public outcry and make government actors see their demands.

These trends at the local level mirrored resistance at the national scale. The Poor People's Campaign is a nation-wide call for a moral revival to address systems of oppression [74]. The campaign carries on the legacy of Dr. Martin Luther King Jr. who led the first Poor People's Campaign in 1968 and uses direct non-violent civil disobedience as one of its main organizing tactics [74]. Human rights are centered in its work, with the list of demands including a fundamental right to clean and affordable water [75]. Rev. William Barber, one of the leaders of the movement, visited Lowndes County, Alabama, in February 2019 in support of the communities struggling with access to safe sanitation and wastewater services [76]. Teri Blanton, a human right to water advocate in Kentucky, attended one of the acts of civil disobedience with the Poor People's Campaign. She recalled "I was carrying my sign about 'lack of clean water is violence'" when she was arrested [77].

The protests advocates and activists engaged in have embraced the human right to water as a philosophy, a strategy, and a slogan. At demonstrations, the human right to water was found in the signs and chants used by activists with "water is a human right" as a common phrase. The role of the human right to water in these actions went beyond the belief in the right, it provided an accessible rallying cry for the people most impacted by unsafe and unaffordable water. It could be plastered on a sign or used as a social media hashtag to develop greater visibility of the water crisis. While the U.S. has made it clear that the country is not bound by the international guarantees of the human right to water, this phrase is symbolic of the struggle that marginalized communities in the country have faced constructing and cementing the right to water from below.

Media and education played a key role in gaining visibility for the movement and exposing governmental failures. Documentary film making and letters to the editors have 
sought to ensure that the general public is exposed to water inequities [29]. Local and international media outlets ranging from MLive in Michigan to The Guardian have provided extensive coverage on water issues that have contributed to shifting perceptions. Lack of access to safe and affordable water is increasingly seen as a human rights violation, and movement actors continue to work with The Guardian to extend their reach to communities that have thus far received less visibility and to build a coalition across the entire country [78].

At the same time, education played a key role for the movement internally to build and strengthen coalitions by training others to continue the work in their own communities [56]. Providing communities with the education, advocacy tools, and resources needed to continue the human right to water struggle has allowed them to successfully respond to the government as they see openings and closings, strategically deciding when to respond with confrontation and cooperation, respectively.

Ultimately, confrontational approaches such as litigating, using human rights mechanisms, and taking to the streets, faced limitations for bringing about change when used on their own. However, such tactics helped uncover openings within the government, such as COVID-19 responses on the state level in Michigan [35]. Similarly, hosting the UN Special Rapporteur on Water and Sanitation in California expanded public knowledge on the crisis while putting pressure on the state government to act. This opened up spaces for further engagement. In this light, confrontational approaches can help expand coalitions and garner attention within local communities as well as national and international audiences.

\subsection{The Capitols}

Advocates did not use confrontational approaches in isolation but complemented them with lobbying, developing policy proposals, suggesting concrete plans, and running for office themselves. In some instances, activists succeeded in identifying or creating openings for engagement in response to what Peter Houtzager and Lucie E. White describe as "heat[ing] up on the streets" [64] (p. 179). Advocates engaged cooperatively in the governmental system in line with Eisinger's (1973) description of relative government "openness" and responsiveness. When a government demonstrates closedness and openness in different parts, social movements voice their demands to the segments of government that are open and willing to listen [38]. Movement actors responded to and took part in the government where they saw openings available to them as a way to balance the confrontational tactics with direct political engagement to push their agenda forward.

\subsubsection{Lobbying and Legislation}

Using their collective power, activists and advocates engaged in lobbying and promoted legislation that embodies the right to water. In Appalachia, Junior Walk from Coal River Mountain Watch lobbied state and federal legislatures for regulations [73]. The West Virginia Rivers Coalition advocated for clean water policy in West Virginia and Washington D.C. to influence regulations and legislation $[79,80]$. Such lobbying and political dialogue resulted in the integration of human rights language in the political sphere.

Residents across the Central Valley in California have been organizing since the late 2000s with a collective goal of passing state-level legislation that recognized the human right to water, supported by organizations such as the Environmental Justice Coalition for Water and the Community Water Center. This coalition was successful in reaching the passing of a bill (Assembly Bill 685), which established that "every human being has the right to safe, clean, affordable, and accessible water adequate for human consumption, cooking, and sanitary purposes" [81], which reflects international human rights standards [82]. The success was largely due to centering the needs of the communities that would benefit the most from this legislation [56]. The movement further supported another bill (Senate, Bill200), which established a safe and affordable water fund seeking to ensure that the human right to water is implemented [83]. 
The passing of Assembly Bill 685 highlighted the multi-pronged approach of confrontational and cooperative tactics, making use of opportunities as they became available to the movement. Assembly Bill 685 had been vetoed by Governor Schwarzenegger before it found success under Governor Brown. As a California water advocate explained, during the bill's second time in the state legislature, the movement was working with internal partners [56]. When the bill was placed in suspense, the movement was made aware and was able to make informed decisions on next steps. As a result, the movement held a press conference near the state Capitol, a confrontational move to apply pressure on the government via media exposure. Advocates simultaneously lobbied representatives on the inside, a cooperative action utilizing the means available to them through the governmental system [56]. They made strategic choices in response to the government's partial closedness, putting the bill in suspense, as well as the simultaneous openness of some parts of the government which they had identified as internal partners. Advocates explained that the combined impact of confrontation via press exposure and cooperation via lobbying, in direct response to these governmental signals, ultimately allowed for the bill to pass successfully [56].

Pointing to the diffusion of rights-based legislation, the federal legislature and other U.S. states have enacted or at least introduced laws dealing with the right to water, some of which directly cite UN documents and resolutions. At the federal level, Representative Tlaib has introduced the Emergency Water is a Human Right Act [84], which has not (yet) been adopted, though. Initiatives in individual U.S. states have found more success. Most recently, due to the advocacy work of environmental groups, New York has adopted the right to clean water in the state constitution alongside the right to clean air and a healthful environment [85]. Other initiatives have been introduced as bills either in the House/Assembly or the Senate of the bicameral legislatures common in U.S. states. Louisiana enacted House Bill 533 in 2017, which has a goal of improving the quality of public drinking water, citing UN General Assembly Resolution 64/292 and General Comment No. 15 by the Committee on Economic, Social and Cultural Rights [86]. Virginia adopted a resolution on the right to water [87]. Ohio saw the introduction of a water bill (House Bill 639) in 2020 which would address affordability of water within the state and also cites UN General Assembly Resolution 64/292 [88]. Similarly, in Minnesota a bill was introduced in both the House (House Bill 1095 Minnesota State Policy) and Senate (Senate Bill 1968 Minnesota State Policy) in 2017 to declare water as a human right. Both suggested bills stated that "[i]t is the policy of the state that every human being has the right to safe, clean, affordable, and accessible water adequate for human consumption, cooking, and sanitary purposes" [89,90], which resembled the language adopted in California. While in their early stages, these legislative initiatives signal that the movement centered on the human right to water has found support from legislators and some success in the political sphere, and advocates continue to call for guarantees for safe and affordable water in the context of infrastructure negotiations [91].

Michigan, a leader in the human right to water movement, has also seen sustained efforts to pass legislation to recognize water as a human right. Most recently, Senate Bill 49 was introduced in 2019 as the "Human right to water act" [92]. Notably, one of the state's Senators who introduced the bill, Stephanie Chang, was an attendee at the 2015 Social Movements Gathering. As in California, Senator Chang's engagement with the movement demonstrates relationship-building and cooperation between advocates and politicians [93]. By forging connections with internal actors, the movement created their own openings to put forth legislation.

However, the U.S. experiences a strained political divide, with Republicans and Democrats often unable to find common ground, which has been a factor in the human right to water movement. For example, in California, Assembly Bill 685 found success in 2012 under a Democratic state legislature and governor, while the bill had been vetoed by Governor Schwarzenegger, a Republican, three years prior [94]. House Bill 533 in Louisiana was successful under a Democratic governor, but the Democratic representative 
who introduced the bill was met with conflict amongst Republican colleagues [95]. In Michigan, despite Democratic Senator Chang's support for human right to water legislation, the state's Republican controlled legislature has stopped the bill from moving forward.

Despite this divide, external factors such as the COVID-19 pandemic can lead to progressive change. Michigan, with a Republican-led state legislature, has seen a shift as the state Senate voted to extend the moratorium on shut-offs [28]. Where Michigan leaders had previously seen water shut-offs as an "urban Black" problem, COVID-19 exposed how water insecurity impacts communities outside of Detroit and Flint (i.e., white, middle-class communities) [35]. COVID-19 has challenged previous narratives that water insecurity is brought on by the people themselves rather than a lack of governmental responsiveness and support, which in turn has resulted in government action.

Constructive engagement also took the form of developing policy proposals such as water affordability plans. Since 2005, Detroit activists have been striving towards a comprehensive water affordability plan [96]. Advocates were aware that the right to water is often perceived as a lofty, aspirational goal, whose implementation faces challenges when confronted with the realities of shrinking cities and decaying infrastructure. To address these challenges head-on, advocates have been engaging with economists and utility specialists such as Roger Colton to design plans that meet the needs of low-income populations while also ensuring financial sustainability. MWRO and many others have cited Philadelphia as a success story in adopting an affordability program [27]. The city established an income-based Tiered Assistance Program (TAP) in 2017 with the goal of achieving affordability for all residents [97]. The program promotes a human right to water framework through its income-based tariff structure to assure accessibility for all regardless of financial ability [97]. Philadelphia Councilwoman Maria D. Quinones-Sanchez stated, in relation to TAP, that "safe drinking water is a basic human right" highlighting political support for the human right to water [95]. For advocates around the country, the TAP model has shown that the human right to water can influence policies to better protect and center the needs of communities.

\subsubsection{Governmental Engagement}

Another common cooperative strategy was direct engagement with political and governmental actors on multiple levels. The organization Martin County Concerned Citizens, for example, enacted its voice and power through direct political engagement. Following a coal slurry spill, the group travelled to Frankfort, Kentucky, to attend the meetings of the Public Service Commission and engage in the public comment section. The initial governmental response to the spill had been lackluster and government actors had talked down to the county's residents, dismissing their concerns. The Public Service Commission meetings served as an opening to the concerned citizens and a space to create visibility [25].

The Alliance for Appalachia used its collective power to bring the voice of the people to the government, combining social engagement with direct political action [98]. Mary Love, a volunteer for Kentuckians for the Commonwealth, an organization tied to The Alliance for Appalachia, spoke to the ways in which the Alliance engaged constructively with the government on the state and federal level, for instance through lobbying days with Senators and Representatives. Under the Obama administration, the Alliance also met with EPA representatives, the Office of Water, the Office of Surface Mining Reclamation and Enforcement, and the Council on Economic Quality, which signaled the government's openness to listen to concerns [98]. This exemplifies how social mobilization and coalition building enabled advocates to transcend the social sphere and enter the political landscape.

Finally, individual actors not only lobbied governments officials, but also ran for office on local, state, and federal levels themselves. This may be the ultimate cooperative strategy of engagement- to take a step into the political system and seek to bring about change from within. Barbi Ann Maynard of Martin County, West Virginia, who has been a long-time advocate for clean and affordable water, bridged the gap between grassroots organizing and 
politics by running for local council [99]. The jump from non-governmental organizations into the political system could also be seen with Laurel Firestone and Maria Herrera, both former staff with the Community Water Center in California. Firestone was appointed in 2019 to the State Water Board by Governor Newsom and Herrera was appointed in 2015 to the California Water Commission by Governor Brown [100,101]. Movement successes in California, such as the passing of Assembly Bill 685, opened governmental opportunities which gave movement leaders direct pathways into the government itself to bring their expertise into decision making processes. Recently, the California Water Boards have conducted surveys on water system financial impacts and household water bill debt demonstrating their concern for affordability [102]. At the federal level, Catherine Flowers, the founder of the Center for Rural Enterprise and Environmental Justice and a long-time water and sanitation advocate [103], has been appointed to the White House Environmental Justice Advisory Council [104].

These examples show how movement actors sought out openings for governmental roles to challenge the current governmental make-up; running for local office is a way to transform trends of unresponsiveness within the government (see [38]). Making these leaps from community-driven engagement to political engagement signifies the desire to translate the demand for the human right to water on the streets to the political landscape as a way to influence change from the inside. While it is too early to determine to what extent advocates in California and West Virginia have been able to bring about change from within, others have noted that persistent activism often creates demand and legitimacy and enables people on the inside to respond [64] (pp. 177-178).

Combined with the confrontational acts in the courts and on the streets, action taken to engage in legislative processes helped drive the human right to water forward into the political space. While advocates chanted "water is a human right" on the streets and human rights mechanisms raised awareness of the water crisis, coalitions of advocates simultaneously approached government institutions with a unified demand for clean, affordable, and accessible water. Through multi-tiered efforts of lobbying, running for office, and introducing right to water legislation, these cooperative approaches were a necessary tactical component of the human right to water movement and found strength through coalitions that united residents, activists, and NGOs.

\section{Conclusions and Outlook}

The right to water movement in the U.S. has socially constructed the right to water from below. In a context with limited legislative recognition and judicial support, a context that can even be considered hostile to socio-economic rights, the movement has succeeded in animating the right to water. Initially, this right was constructed in the social sphere from the ground up with subsequent influences on legislation, policy, institutions, and service provision, demonstrating the success of the movement. The right has been propelled through various confrontational and cooperative approaches in the courts, on the streets, and at the Capitols. Advocates used adversarial approaches: protests and civil disobedience; reliance on human rights mechanisms; and litigation to a more limited extent. These confrontational approaches occurred simultaneously with the development of concrete proposals and plans for ensuring water affordability and engaging with Representatives such as Stephanie Chang during the Social Movements Gathering in Detroit. There was no clear sequencing between confrontational and cooperative strategies, but we saw a swinging pendulum between cooperative and confrontational approaches as the movement read both signals of open and closed governments. Advocates made strategic choices in response to past experience and government reactions. Where government spaces were closed, activists heated up and increased the pressure through adversarial approaches. Where spaces opened up, advocates engaged, cooperated, developed constructive proposals, pointed to successes elsewhere, and became part of the process. If such constructive engagement did not move the needle as seen in Detroit after years of discussions over 
suggested affordability plans, advocates returned to adversarial approaches. The right to water movement has embraced confrontational and cooperative approaches persistently.

External factors have influenced-and are likely to continue to influence- the movement, including the political divide in the U.S., global health crises such as COVID-19, and larger social movements such as Black Lives Matter. Continuing to educate the public on how these and other factors intersect with the realization of the human right to water will be crucial for the movement's success moving forward. The multi-pronged approach of agitation, litigation, and legislation has led to successes for the human right to water movement and advocates and activists will likely continue using these approaches to advance the movement.

Author Contributions: Both authors made substantial contributions to this research; I.T.W. largely conceptualized the study with S.K.'s support; S.K. collected and analyzed the data; S.K. and I.T.W. jointly drafted the manuscript through multiple rounds of revisions; I.T.W. acquired the funding. All authors have read and agreed to the published version of the manuscript.

Funding: This research was supported by the Research Council of Norway under the Grant "Elevating water rights to human rights: Has it strengthened marginalized people's claim for water?" (263096), as well as the Institute for the Study of Human Rights and the Graduate School of Arts and Sciences at Columbia University.

Institutional Review Board Statement: The study was conducted in accordance with the Declaration of Helsinki, and the project was reviewed by Columbia University's Institutional Review Board under Protocol Number IRB-AAAR7902 (last approved on 3 December 2020).

Informed Consent Statement: All participants gave their written informed consent for inclusion before they participated in the study.

Acknowledgments: We gratefully acknowledge the opportunity to present this research as work in progress at a workshop organized by the project on "Elevating water rights to human rights" at the Center for Law and Social Transformation in Bergen, Norway, and the Department of Legal Studies at the Central European University in Vienna, Austria, as well as insightful comments provided on an earlier draft of this article by Amanda Klasing and the Special Issue editors. Above all, we greatly appreciate the time and commitment of our interview participants who have shared their insights.

Conflicts of Interest: The authors declare no conflict of interest.

\section{References}

1. Fedinick, K.P.; Wu, M.; Panditharatne, M.; Olson, E.D. Threats on Tap: Widespread Violations Highlight Need for Investment in Water Infrastructure and Protections; Natural Resource Defense Council: New York, NY, USA, 2017; pp. 1-26.

2. United States Water Alliance. An Equitable Water Future: A National Briefing Paper; US Water Alliance: Washington, DC, USA, 2017; pp. 1-68.

3. Lakhani, N. Millions of Americans Can't Afford Water, as Bills Rise 80\% in a Decade. Consumer Reports. 10 July 2020. Available online: https: / www.consumerreports.org/personal-finance/millions-of-americans-cant-afford-water-as-bills-rise-80-percentin-a-decade-a8273700709 (accessed on 31 July 2021).

4. Food and Water Watch. America's Secret Water Crisis: National Shut Off Survey Reveals Water Affordability Emergency Affecting Millions; Food and Water Watch: Washington, DC, USA, 2018; Available online: https://www.foodandwaterwatch.org/wpcontent/uploads/2021/03/rpt_1810_watershutoffs-web2.pdf (accessed on 31 July 2021).

5. US Water Alliance. Closing the Water Access Gap in the United States: A National Action Plan; US Water Alliance: Washington, DC, USA, 2019; Available online: http:/ / uswateralliance.org/sites/uswateralliance.org/files/publications/Closing\%20the\%20 Water\%20Access\%20Gap\%20in\%20the\%20United\%20States_DIGITAL.pdf (accessed on 31 July 2021).

6. Aka, P.C. Analyzing U.S. Commitment to Socioeconomic Human Rights. Akron. Law Rev. 2006, 39, 1-48.

7. Albisa, C. Drawing Lines in the Sand: Building Economic and Social Rights in the United States. In Human Rights in the United States: Beyond Exceptionalism; Hertel, S., Libal, K., Eds.; Cambridge University Press: Cambridge, UK, 2011.

8. United Nations General Assembly. 64th Session, 108th Plenary Meeting U.N. Doc A/64/PV.108, New York, NY, USA. 28 July 2010. Available online: https:/ / undocs.org/A/64/PV.108 (accessed on 31 July 2021).

9. Kelly, B. Statement on Agenda Item 70: The Human Rights to Safe Drinking Water and Sanitation. Presented at the United States Mission to the United Nations, New York, NY, USA, 18 November 2019; Available online: https:/ / usun.usmission.gov / unitedstates-statement-on-agenda-item-70-the-human-rights-to-safe-drinking-water-and-sanitation (accessed on 31 July 2021). 
10. Pompeo, M.; Haley, N. Remarks on the UN Human Rights Council. Presented at the United States Mission to the United Nations, Washington, DC, USA, 19 June 2018; Available online: https://geneva.usmission.gov/2018/06/21/remarks-on-the-un-humanrights-council (accessed on 31 July 2021).

11. Gonzalez, C.G. Environmental Racism, American Exceptionalism, and Cold War Human Rights. Transnatl. Law 2017, 26, 281-315.

12. Lewis, H. "New" Human Rights? U.S. Ambivalence Toward the International Economic and Social Rights Framework. In Bringing Human Rights Home: A History of Human Rights in the United States; Soohoo, C., Albisa, C., Davis, M.F., Eds.; University of Pennsylvania Press: Philadelphia, PA, USA, 2008; pp. 103-144.

13. Way, S.-A. The "Myth" and Mystery of US History on Economic, Social, and Cultural Rights: The 1947 "United States Suggestions for Articles to be Incorporated in an International Bill of Rights". Hum. Rights Q. 2014, 36, 869-897. [CrossRef]

14. Neier, A. Social and Economic Rights: A Critique. Hum. Rights Brief 2006, 13, 1-3.

15. Roth, K. Defending Economic, Social and Cultural Rights: Practical Issues Faced by an International Human Rights Organization. Hum. Rights Q. 2004, 26, 63-73. [CrossRef]

16. Partners for Dignity \& Rights. Mission. Available online: https://Dignityandrights.Org/about/Mission-Vision (accessed on 31 July 2021).

17. Bob, C. Bringing Human Rights Home? The Promises and Pitfalls of Rights Strategies in American Social Justice Advocacy. Proc. Annu. Meet. Am. Soc. Int. Law 2007, 101, 82-84. [CrossRef]

18. Tsutsui, K.; Whitlinger, C.; Lim, A. International Human Rights Law and Social Movements: States' Resistance and Civil Society's Insistence. Annu. Rev. Law. Soc. Sci. 2012, 8, 367-396. [CrossRef]

19. The New York Times. Full Transcript: Democratic Presidential Debates, Night 1. The New York Times. 26 June 2019. Available online: https:/ /www.nytimes.com/2019/06/26/us/politics/democratic-debate-transcript.html (accessed on 14 July 2020).

20. Biden, J. Housing Should Be a Right-Not a Privilege. But Far Too Many Americans Lack Access to Affordable, Quality, and Safe Housing. Today, I'm Releasing My \$640 Billion Plan to Change That. 11:13 a.m. Twitter. 24 February 2020. Available online: https:/ / twitter.com/joebiden/status/1231975321311694849 (accessed on 31 July 2021).

21. Sanders, B.; Lawrence, B. Clean Water is a Human Right. In America It's More a Profit Machine. The Guardian. 23 June 2020. Available online: https://www.theguardian.com/us-news/commentisfree/2020/jun/23/clean-water-should-be-an-americanhuman-right-not-a-government-profit-machine (accessed on 14 July 2020).

22. Kozikis, S.; Winkler, I.T. The Paradox of Framing Water as a Human Right in the United States: An Analysis of Power and Resistance. J. Hum. Rights 2020, 19, 464-483. [CrossRef]

23. Braun, V.; Clarke, V. Using Thematic Analysis in Psychology. Qual. Res. Psychol. 2006, 3, 77-101. [CrossRef]

24. The Alliance for Appalachia. About Us. Available online: https://Theallianceforappalachia.Org/Mission-Values/ (accessed on 31 July 2021).

25. McCoy, N. Martin County, KY, USA. Personal communication, 25 July 2018.

26. Firestone, L. Sacramento, CA, USA. Personal communication, 21 June 2018.

27. Orduño, S. Detroit, MI, USA. Personal communication, 18 July 2018.

28. Fancher, M. Detroit, MI, USA. Personal communication, 16 December 2020.

29. Jones, P. Washington, DC, USA. Personal communication, 21 December 2020.

30. People's Tribune. International Social Movements Gathering on Water and Affordable Housing, Detroit, MI. People's Tribune. July 2015. Available online: http:/ / peoplestribune.org/pt-news/2015/06/international-social-movements (accessed on 14 July 2020).

31. Gauri, V.; Brinks, D.M. Courting Social Justice: Judicial Enforcement of Social and Economic Rights in the Developing World; Cambridge University Press: Cambridge, UK, 2009.

32. Winkler, I.T. Socio-economic rights: Consolidating progress, charting future directions. In A Research Agenda for Human Rights; Stohl, M., Brysk, A., Eds.; Edgar Elgar Publishing: Cheltenham, UK, 2020; pp. 111-125.

33. Hertel, S. Hungry for Justice: Social Mobilization on the Right to Food in India. Dev. Chang. 2014, 46, 72-94. [CrossRef]

34. Polletta, F.; Jasper, J.M. Collective Identity and Social Movements. Annu. Rev. Sociol. 2001, 27, 283-305. [CrossRef]

35. Jennings, A.; Detroit, MI, USA. Personal communication, 11 December 2020.

36. Meyer, D.S.; Minkoff, D.C. Conceptualizing Political Opportunity. Soc. Forces 2004, 82, 1457-1492. [CrossRef]

37. Tarrow, S. Power in Movement, 2nd ed.; Cambridge University Press: Cambridge, UK, 1994.

38. Eisinger, P.K. The Conditions of Protest Behavior in American Cities. Am. Political Sci. Rev. 1973, 67, 11-28. [CrossRef]

39. Minkoff, D.C. From Service Provision to Institutional Advocacy: The Shifting Legitimacy of Organizational Forms. Soc. Forces 1994, 72, 943-969. [CrossRef]

40. Kitschelt, H.P. Political Opportunity Structures and Political Protest: Anti-Nuclear Movements in Four Democracies. Brit. J. Polit. Sci. 1986, 16, 57-85. [CrossRef]

41. Adams, A.E.; Shriver, T.E. Challenging Extractive Industries: How Political Context and Targets Influence Tactical Choice. Sociol. Perspect. 2016, 59, 892-909. [CrossRef]

42. Perelman, J.; White, L.E. Experience and Theory in African Economic and Social Rights Activism. In Stones of Hope; White, L.E., Perelman, J., Eds.; Stanford University Press: Stanford, CA, USA, 2011; pp. 149-171.

43. Finnegan, A.C.; Saltsman, A.P.; White, S.K. Negotiating Politics and Culture: The Utility of Human Rights for Activist Organizing in the United States. J. Hum. Rights Pract. 2010, 2, 307-333. [CrossRef]

44. Sellers, M. Universal Human Rights in the Law of the United States. Am. J. Comp. Law 2010, 58, 533-553. [CrossRef] 
45. Schwartz, B.; Berkeley, CA, USA. Personal communication, 18 June 2018.

46. Kitaba-Gabiglio, B.; Detroit, MI, USA. Personal communication, 21 December 2020.

47. Lyda et al. v. City of Detroit; Case No. 13-53846; Bankr. E.D. Mich. 19 November 2014. Available online: https://casetext.com/ case/lyda-v-city-of-detroit-in-re-city-of-detroit-2 (accessed on 31 July 2021).

48. McGehee, C.S. Lyda et al. v. City of Detroit. Brief Amicus Curiae of International Network for Economic, Social, and Cultural Rights. ESCR-Net. 3 February 2015. Available online: https://www.escr-net.org/sites/default/files/Detroit $\% 20$ water\%20case\% 20amicus\%20-\%20FINAL\%20as\%20filed\%20(3\%20Feb\%202015).pdf (accessed on 31 July 2021).

49. ACLU Fund of Michigan. Civil Rights Coalition Files Class Action Lawsuit Challenging Detroit Water Shutoff Policy. ACLU Michigan. 9 July 2020. Available online: https://www.aclu.org/press-releases/civil-rights-coalition-files-class-action-lawsuitchallenging-detroit-water-shutoff (accessed on 31 July 2021).

50. De Albuquerque, C. Report of the Special Rapporteur on the Human Right to Safe Drinking Water and Sanitation. United Nations General Assembly, UN Doc A/HRC/18/33/Add.4. 2 August 2011. Available online: https://undocs.org/A/HRC/18/33/Add.4 (accessed on 31 July 2021).

51. De Albuquerque, C.; Farha, L. Joint Press Statement by Special Rapporteur on Adequate Housing as a Component of the Right to an Adequate Standard of Living and to Right to Non-Discrimination in this Context, and Special Rapporteur on the Human Right to Safe Drinking Water and Sanitation, Visit to City of Detroit (United States of America) 18-20 October 2014. United Nations. October 2014. Available online: https://www.ohchr.org/EN/NewsEvents/Pages/DisplayNews.aspx?NewsID=15188\&LangID= E (accessed on 31 July 2021).

52. Alston, P.; Farha, L.; Heller, L. Allegation Letter USA 2/2016. Office of the High Commissioner for Human Rights. 5 April 2016. Available online: https://spcommreports.ohchr.org/TMResultsBase/DownLoadPublicCommunicationFile?gId=18792 (accessed on 31 July 2021).

53. United Nations General Assembly. Report of the Working Group of Experts on People of African Descent on its Mission to the United States of America; U.N. Doc A/HRC/33/61/Add.2; United Nations General Assembly: Geneva, Switzerland, 18 August 2016; Available online: https://undocs.org/en/A/HRC/33/61/Add.2 (accessed on 31 July 2021).

54. Pilkington, E. A Journey through a Land of Extreme Poverty: Welcome to America. The Guardian. 15 December 2017. Available online: theguardian.com/society/2017/dec/15/america-extreme-poverty-un-special-rapporteur (accessed on 19 September 2021).

55. Alston, P. Oral Statement by Mr. Philip Alston Special Rapporteur on Extreme Poverty and Human Rights. Presented at the 38th Session of the Human Rights Council, Geneva, Switzerland, 22 June 2018. Available online: https://www.ohchr.org/EN/ NewsEvents / Pages / DisplayNews.aspx?NewsID=23243 (accessed on 31 July 2021).

56. California Advocate; California, CA, USA. Personal communication, 30 December 2021.

57. Charlesworth, H.; Larking, E. Introduction: The Regulatory Power of the Universal Periodic Review. In Human Rights and the Universal Periodic Review: Rituals and Ritualism; Charlesworth, H., Larking, E., Eds.; Cambridge University Press: Cambridge, UK, 2015.

58. Human Rights Council. Report of the Working Group on the Universal Periodic Review; 13th Session, U.N. Doc A/HRC/30/12; 58; Human Rights Council: Geneva, Switzerland, 2015; Available online: https:/ /undocs.org/A/HRC/30/12 (accessed on 31 July 2021).

59. Human Rights Council. UPR of United State of America: Thematic List of Recommendations; 3rd Cycle, 36th Session; Human Rights Council: Geneva, Switzerland, 2020; Available online: http:/ /lib.ohchr.org/HRBodies/UPR/Documents/session36/US/UPR36_ United\%20States\%20of\%20America_Thematic_List_of_Recommendations.docx (accessed on 31 July 2021).

60. U.S. Mission Geneva. U.S. UPR Working Groups: 2016 Year-End Summary; U.S. Mission to International Organizations in Geneva; US Mission Geneva: Geneva, Switzerland, 11 January 2017. Available online: https://geneva.usmission.gov/2017/01/17/u-supr-working-groups-2016-year-end-summary/ (accessed on 31 July 2021).

61. Landy, R.; USA. Personal communication, 23 December 2020.

62. Inter-American Commission on Human Rights. Access to Water in the Americas: An Introduction to the Human Right to Water in the Inter-American System; Annual Report 2015; Inter-American Commission on Human Rights: San José, Costa Rica, 2015; pp. 458-503. Available online: http://www.oas.org/en/iachr/docs/annual/2015/doc-en/InformeAnual2015-cap4A-agua-EN. pdf (accessed on 4 September 2020).

63. Inter-American Commission on Human Rights. EEUU: Acceso al Agua. YouTube. 2016. Available online: https://www.youtube. $\mathrm{com} /$ watch? $\mathrm{v}=\mathrm{uNqNhuNnFWE}$ (accessed on 4 September 2020).

64. Houtzager, P.; White, L.E. The Long Arc of Pragmatic Economic and Social Rights Advocacy. In Stones of Hope; White, L.E., Perelman, J., Eds.; Stanford University Press: Palo Alto, CA, USA, 2010; pp. 172-194. [CrossRef]

65. Pauli, B.J. The Long Road Out of Crisis: (Re)Building Trust in Flint's Public Water from Poisoning to Pandemic. In Public Water and COVID-19: Dark Clouds and Silver Linings; McDonald, D.A., Spronk, S., Chavez, D., Eds.; Municipal Services Project: Kingston, ON, Canada; Transnational Institute: Amsterdam, The Netherlands; Latin American Council of Social Sciences: Buenos Aires, Argentina, 2021; pp. 311-328.

66. Chapman, M.M. Hundreds in Detroit Protest Over Move to Shut Off Water. The New York Times. 18 July 2014. Available online: https:/ / www.nytimes.com/2014/07/19/us/protesters-picket-detroit-over-move-to-shut-off-water.html (accessed on 14 July 2020). 
67. Terry, N. Group Rallies against Water Shutoffs in Detroit. The Detroit News. 23 April 2018. Available online: https://www. detroitnews.com/story/news/local/detroit-city/2018/04/23/group-rallies-detroit-water-shutoffs/34172799 (accessed on 31 July 2021).

68. Clark, C. Water Justice Struggles as a Process of Commoning. Community Dev. J. 2018, 54, 80-99. [CrossRef]

69. Levy, K. I Do Mind Dying; Vimeo: Detroit, MI, USA, 2014. Available online: https:/ /vimeo.com/99499580 (accessed on 31 July 2021).

70. Murthy, S.L. A New Constitutive Commitment to Water. Boston Coll. J. Law Soc. Justice 2016, 36, $159-233$.

71. Dickson, J.D. Almost 3 Years Later, Homrich 9 Appear Headed to Court. The Detroit News. 10 October 2017. Available online: https:/ / www.detroitnews.com/story/news/local/detroit-city/2017/01/10/homrich-water-shutoffs-court/96396538 (accessed on 6 August 2021).

72. Cwiek, S. Three Years after Arrests, Charges against Detroit Water Protesters Dismissed. Michigan Radio. 2017. Available online: https:/ / www.michiganradio.org/law/2017-06-20/three-years-after-arrests-charges-against-detroit-water-protestersdismissed (accessed on 2 November 2021).

73. Walk, J.; Naoma, WV, USA. Personal communication, 26 July 2018.

74. Poor People's Campaign. About Us. Available online: https://www.poorpeoplescampaign.org/about (accessed on 31 July 2021).

75. Poor People's Campaign. Our Demands. Available online: https://www.poorpeoplescampaign.org/about/our-demands (accessed on 31 July 2021).

76. Contreras, R. Poor People's Campaign: Eyes Low-Income Voters in 13 States. The Washington Post. August 2020. Available online: https: / / www.washingtonpost.com/national/religion/poor-peoples-campaign-eyes-low-income-voters-in-13-states / 2020/08/11/060551c6-db88-11ea-b4f1-25b762cdbbf4_story.html (accessed on 6 August 2021).

77. Blanton, T.; Berea, KY, USA. Personal communication, 24 July 2018.

78. The Guardian. Have You Faced Local Sanitation Issues in the US? We Want to Hear from You. The Guardian. 11 February 2021. Available online: https://www.theguardian.com/us-news/2021/feb/11/sanitation-sewage-community-tell-us (accessed on 19 September 2021).

79. Rosser, A.; Charleston, WV, USA. Personal communication, 23 July 2018.

80. West Virginia Rivers Coalition. About Us. Available online: Https://Wvrivers.Org/about/about-Us (accessed on 6 August 2021).

81. California, Assem. Bill 685, 2012 Reg. Sess., Cal. Stat. 2012. Available online: https://leginfo.legislature.ca.gov/faces/ billNavClient.xhtml?bill_id=201120120AB685 (accessed on 6 August 2021).

82. Winkler, I.T. The Human Right to Water: Significance, Legal Status and Implications for Water Allocation, 1st ed.; Hart Publishing: Oxford, UK, 2012.

83. California, Sen. Bill 200, 2019 Reg. Sess., Cal. Stat. 2019. Available online: https://leginfo.legislature.ca.gov/faces/billTextClient. xhtml?bill_id=201920200SB200 (accessed on 6 August 2021).

84. U.S. Congress. Emergency Water Is a Human Right Act of 2021. H.R.616. 117th Cong. Available online: https://www.Congress Gov/Bill/117th-Congress/House-Bill/616 (accessed on 19 September 2021).

85. Gutiérrez, N.; Keegan, B. Environmental Rights Amendment Passes in New York. Earthjustice. 3 November 2021. Available online: https:/ / earthjustice.org/news/press/2021/environmental-rights-amendment-passes-in-new-york (accessed on 10 November 2021).

86. Louisiana, House Bill 533, 2017 Reg. Sess., La. Stat. 2017. Available online: http:/ /www.legis.la.gov/legis/BillInfo.aspx?s=17 $\mathrm{RS} \& b=\mathrm{HB} 533 \&$ sbi=y (accessed on 6 August 2021).

87. Virginia, House Bill HJ 538, 2021 Reg. Sess., Va. Stat. 2021. Available online: https://lis.virginia.gov/cgi-bin/legp604.exe?211+ sum + HJ538 (accessed on 10 August 2021).

88. Ohio, House Bill 639, 2019 Reg. Sess., Ohio Stat. 2019. Available online: https:/ / www.legislature.ohio.gov/legislation/legislationsummary?id=GA133-HB-639 (accessed on 6 August 2021).

89. Minnesota, House Bill 1095, 2017 Reg. Sess., Minn. Stat. 2017. Available online: https://www.revisor.mn.gov/bills/bill.php?b= house\&f=HF1095\&ssn=0\&y=2017 (accessed on 6 August 2021).

90. Minnesota, Sen. Bill 1968, 2017 Reg. Sess., Minn. Stat. 2017. Available online: https://www.revisor.mn.gov/bills/bill.php?b=

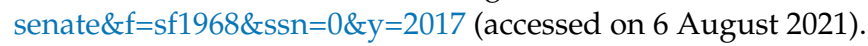

91. Human Rights Watch. US: Advance Human Right to Safe, Affordable Water. Human Rights Watch. 8 September 2021. Available online: https:/ / www.hrw.org/news/2021/09/08/us-advance-human-right-safe-affordable-water (accessed on 19 September 2021).

92. Michigan, Senate Bill 49, 2019 Reg. Sess., Mich. Stat. 2019. Available online: http://legislature.mi.gov/doc.aspx?2019-SB-0049 (accessed on 15 November 2021).

93. Unitarian Universalist Service Committee. In Their Own Words: What We Need is Affordability. Available online: https: / / www.uusc.org/in-their-own-words-what-we-need-is-affordability (accessed on 14 July 2020).

94. Walton, B. California Right to Water Bill Vetoed. Available online: https:/ / www.circleofblue.org/2009/world/california-right-towater-bill-vetoed (accessed on 17 January 2021).

95. Gagliano, K. Bad Blood Boils over Bad Water. Available online: https://www.dailyworld.com/story/news/2017/05/18/badblood-boils-over-bad-water/101828564/ (accessed on 17 January 2021). 
96. Colton, R. A Water Affordability Program for the Detroit Water and Sewerage Department (DWSD); Fisher, Sheehan \& Colton Public Finance and General Economics: Belmont, MA, USA, 2005.

97. City of Philadelphia. Philadelphia Launches New, Income-Based, Tiered Assistance Program. Available online: https://www. phila.gov/press-releases/mayor/philadelphia-launches-new-income-based-tiered-assistance-program/ (accessed on 14 July 2020).

98. Love, M.; Berea, KY, USA. Personal communication, 24 July 2018.

99. Maynard, B.A.; Warfield, KY, USA. Personal communication, 25 July 2018.

100. California Water Boards. Meet the Board Members. Available online: https://www.Waterboards.ca.Gov/About_us/Board_ members (accessed on 9 August 2021).

101. Community Water Center. Governor Brown Announces Maria Herrera's Appointment to the CA Water Commission! Community Water Center. 2015. Available online: https:/ / www.communitywatercenter.org/sadwf_bi_partisan_vote (accessed on 14 July 2020).

102. California Water Boards. Drinking Water COVID-19 Financial Impacts Survey. 2021. Available online: https://www.waterboards. ca.gov / drinking_water/certlic/drinkingwater/covid-19watersystemsurvey.html (accessed on 19 September 2021).

103. Flowers, C.C.; Kamuf Ward, J.; Winkler, I.T. Flushed and Forgotten: Sanitation and Wastewater in Rural Communities in the United States; The Alabama Center for Rural Enterprise: Lowndes County, AL, USA; The Columbia Law School Human Rights Clinic: New York, NY, USA; The Institute for the Study of Human Rights at Columbia University: New York, NY, USA, 2019; pp. 1-56.

104. The White House. White House Announces Environmental Justice Advisory Council Members. 29 March 2021. Available online: https: / /www.whitehouse.gov/ceq/news-updates/2021/03/29/white-house-announces-environmental-justice-advisorycouncil-members (accessed on 19 September 2021). 